PKM CRAFTS OF INU AND SAGU DUPLING SAGU DASA WISMA MELATI 2 SOUTH SIBERUT MENTAWAI ISLANDS

\title{
PKM KERAJINAN INU DAN KERUPUK SAGU DASA WISMA MELATI 2 SIBERUT SELATAN KEPULAUAN MENTAWAI
}

\author{
Alfattoy Rheza Syahrul ${ }^{1}$, Kaksim $^{2}$, Jimi Ronald ${ }^{3}$ \\ 1,2,3 STKIP PGRI Sumatera Barat \\ E-mail: Alfattory r@yahoo.com, kaksim010983@gmail.com, jimironaldstkippgrisumbar@gmail.com
}

\begin{abstract}
The main issues in this service are related to sales and attractiveness and understanding related to product promotion. As well as the basis for using online applications, e-Commerce implementation requires a fundamental paradigm shift, from the original marketplace that emphasizes physical interaction between sellers and buyers into a market space that relies on electronic transactions. In a traditional marketplace, information, product / service, and payment traffic is physical (location based). In other words, the applicable business model is the geographic business model. Conversely, in a virtual marketplace, product information flow, communication processes between producers and consumers, distribution of goods / services and transactions take place in a virtual / virtual world. The purpose of this service is to improve the production process and the process of selling and utilizing resources in activities and choosing the right marketing channels as well as in the use of media so that the Jasmine 2 group in Batjoja Hamlet is one of the business actors that produce local processed products in Siberut District South. These service methods are outreach, activity assistance, attractive product packaging, online marketing management and activity evaluation. The result of this dedication is that the effort is socialized in this service through social media such as IG, and BUKALAPAK https://www. bukalapak.com/u/craftsinukerupuksagu. Brands and packaging have been designed in such a way and are expected to be increasingly recognized, the Service Team has also provided debriefing to partners in the form of "Smart Packaging" through training and outreach on suitable and appropriate packaging in attracting prospective customers, "standing poch" packaging with seals, which is more flexible and attractive in various sizes. The packaging is ready to be affixed to a complete brand sticker with the label. And many orders have arrived, especially from outside the Mentawai Islands district. Conclusion Melati 2 Group in running a business has the potential to produce value and money. Although the sales of the products produced namely inu craft and sago crackers are getting better locally but the equal distribution of sales and marketing of products is very good and many are interested, but it's just that the potential for promotion must always be done, especially for marketing outside the Island or outside the Regency so that in improving the economic partner groups in particular will increasingly step up. This is also based on information and education held by partner groups in terms of the production process and marketing selection.
\end{abstract}

Keywords: inu, kerupuk sagu

\section{ABSTRAK}

Pokok permasalahan dalam pengabdian ini adalah terkait penjualan dan daya tariknya serta pemahaman terkait dengan promosi produk. Serta dasar penggunaan aplikasi online yakni, Implementasi e-Commerce menuntut pergeseran paradigma secara fundamental, dari yang semula marketplace yang menekankan interaksi secara fisik antara penjual dan pembeli menjadi 


\section{Rangkiang: Lurna/ Pengabdian Pada Masyarakat UPSM STKIP PGR/ Sumatera Barat}

ISSN: (2721-2688) Vol. 1, Vo, 2 (Desember 2019): 41- 52

https://doi.org/10.22202/JR.2020.V1i2.3821

marketspace yang mengandalkan transaksi elektronik. Dalam traditional marketplace, lalu lintas informasi, produk/jasa, dan pembayaran bersifat fisik (location based). Dengan kata lain, model bisnis yang berlaku adalah geographic business model. Sebaliknya, dalam dunia virtual marketplace, aliran informasi produk, proses komunikasi antara produsen dan konsumen, distribusi barang/jasa dan transaksi berlangsung dalam dunia maya/virtual. Tujuan dari pengabdian ini adalah perbaikan proses produksi serta proses penjualan dan pemanfaatan sumberdaya dalam berkegiatan serta memilih saluran pemasaran yang tepat juga dalam penggunaan media sehingga kelompok melati 2 yang ada di Dusun Batjoja merupakan salah satu pelaku usaha yang menghasilkan produk Olahan Asli lokal ada di Kecamatan Siberut Selatan. Metode pengabdian ini adalah sosialisasi, pendampingan kegiatan, pengemasan produk yang menarik, pengelolaan pemasaran secara daring dan evaluasi kegiatan. Hasil dari pengabdian ini adalah Usaha tersebut di sosialisasikan dalam pengabdian ini melalui media sosial seperti IG, dan BUKALAPAK https://www.bukalapak.com/u/kerajinaninukerupuksagu. Merek dan kemasan telah di desain sedemikian rupa dan diharapkan akan semakin dikenal, Tim Pengabdi juga telah memberikan pembekalan untuk mitra berupa "Smart Packaging" melalui pelatihan dan sosialisasi mengenai kemasan yang cocok dan tepat dalam menarik calon pelanggan, kemasan "standing poch" dengan seal, yang lebih fleksibel dan menarik dengan berbagai ukuran. Kemasan sudah siap untuk ditempel stiker merek lengkap dengan labelnya. Serta telah banyak pesanan berdatangan terutama dari luar kabupaten Kepulauan Mentawai. Kesimpulan Kelompok Melati 2 dalam menjalankan usaha mempunyai potensi dalam menghasilkan nilai dan uang. Meskipun penjualan dari produk yang dihasilkan yakni kerajinan inu dan kerupuk sagu sudah semakin bagus secara lokal namun pemerataan penjualan dan pemasaran produk sudah Sangat bagus dan banyak yang berminat, namun hanya saja potensi promosi yang dilakukan harus selalu dilakukan, terlebih untuk pemasaran diluar Pulau ataupun luar Kabupaten sehingga dalam peningkatan ekonomi kelompok mitra khususnya akan semakin meningkati. Hal ini juga didasari oleh informasi dan edukasi yang dimiliki oleh kelompok mitra dalam hal proses produksi dan pemilihan pemasaran.

Kata kunci : inu, kerupuk sagu

\section{PENDAHULUAN}

Berdasarkan UU No.20 Tahun 2008 pasal 3 telah menjelaskan bahwa UMKM bertujuan menumbuhkan dan mengembangkan usahanya dalam rangka membangun perekonomian nasional berdasarkan demokrasi ekonomi yang berkeadilan. Perkembangan usaha mikro kecil dan menengah (UMKM) memiliki potensi yang besar dalam meningkatkan taraf hidup masyarakat dikarenakan sektor UMKM memiliki pasar yang luas dan mampu menyerap tenaga kerja sehingga dapat menekan tingkat pengangguran dan kemiskinan. Salah satu upaya pemerintah untuk memperkuat perekonomian saat ini adalah dengan terus memberdayakan Usaha Kecil dan Menengah (UMKM).

Keberadaan UMKM memang tidak diragukan lagi, dimana pada saat terjadinya krisis ekonomi secara global hanya UMKM usaha yang mampu bertahan di tengah krisis dan menjadi penggerak roda perekonomian. Hal ini disebabkan karena sebagian besar atau hampir $99 \%$ UMKM di Indonesia adalah usaha mikro di sektor informal dan pada umumnya menggunakan bahan baku lokal dengan pasar lokal. Sehingga menyebabkan UMKM tidak terpengaruh secara langsung oleh krisis global. Berdasarkan obeservasi yang dilakukan pada pelaku usaha mikro Siberut selatan, kendala yang dihadapi pelaku usaha kecil untuk mengembangkan usaha adalah masalah penjualan, kekurangan faktor produksi, distribusi pemasaran dan untuk pengenalan produk asli daerah ke masyarakat luar. Beberapa dari kendala yang dihadapi oleh usaha kecil tersebut telah dicoba dicari solusinya tetapi selalu 


\section{Rangkiang: Lurna/ Pengabdian Pada Masyarakat LPSM STKIP PGR/ Sumatera Barat}

ISSN: (2721-2688) Vol. 1, Vo, 2 (Desember 2019): 41- 52

https://doi.org/10.22202/JR.2020.V1i2.3821

mengalami kegagalan karena kepulauan mentawai merupakan salah satu daerah yang sangat sulit di jangkau oleh konsumen.

Salah satu jenis UMKM yang banyak digeluti oleh masyarakat di wilayah kepulauan Mentawai adalah usaha industri kerajinan Inu dan industri makanan ringan Kerupuk Sagu. Hampir semua daerah yang ada di kepulauan mentawai akan dijumpai pembuat kerajinan dan makanan ini, karena kerajinan dan makanan ini cukup digemari oleh masyarakat mentawai. Biasanya kerajinan Inu ini sebagai perhiasan untuk acara pesta adat sedangkan makanan kerupuk sagu ini sebagai teman pada saat minum teh atau sebagai pengganti kerupuk bagi orang mentawai ketika makan. Di Kecamatan Siberut Selatan cukup banyak masyarakatnya yang ingin menggeluti usaha pembuatan kerajinan Inu dan makanan ringan Kerupuk Sagu, tapi hanya sebagian kecil saja yang mau memulai usaha dengan sungguh-sungguh.

UMKM yang menjadi bagian dari Program mitra ini akan dilaksanakan di Desa Maileppet Kecamatan Siberut Selatan. Menurut Data BPS tahun 2015 terletak dengan jarak $160 \mathrm{Km}$ dari pusat Kota Padang. Luas wilayah Kepulauan Mentawai $6.001,35 \mathrm{~km}^{2}$ yang terdiri dari 10 kecamatan yang terdiri dari Pagai Selatan dengan luas wilayah $901,08 \mathrm{~km}^{2}$, Sikakap dengan luas wilayah $278,5 \mathrm{~km}^{2}$, Pagai Utara dengan luas wilayah $342,02 \mathrm{~km}^{2}$, Sipora Selatan dengan luas wilayah $268,47 \mathrm{~km}^{2}$, Sipora Utara dengan luas wilayah $383,08 \mathrm{~km}^{2}$, Siberut Selatan dengan luas wilayah $508,33 \mathrm{~km}^{2}$, Siberut Barat Daya dengan luas wilayah $649,08 \mathrm{~km}^{2}$, Siberut Tengah dengan luas wilayah $739,87 \mathrm{~km}^{2}$, Siberut Utara dengan luas wilayah $816,11 \mathrm{~km}^{2}$, dan Siberut Barat dengan luas wilayah 1.124, $86 \mathrm{~km}^{2}$.

Berdasarkan kegiatan yang telah dilakukan oleh tim PKM bahwa wilayah Kecamatan Siberut Selatan mempunyai potensi untuk mengembangkan usahanya salah satunya telah dijumpai adanya kelompok usaha yang sudah lama bergerak dibidang kerajinan Inu dan makanan ringan Kerupuk Sagu. Bahan baku untuk pembuatan kerajinan Inu adalah ikat pinggang yang mudah untuk didapatkan, manik2 dan aksesori. sedangkan bahan baku dari makanan ringan kerupuk sagu adalah Sagu yang merupakan makanan pokok sehari - hari masyarakat mentawai yang mudah dijumpai.

Pelaku usaha kerajinan Inu dan makanan ringan Kerupuk Sagu ini sudah aktif menghasilkan produksi selama \pm 2 tahun. Usaha ini dikelola oleh pemilik secara kekeluargaan. Peminat dari kerajinan Inu dan makanan ringan Kerupuk Sagu ini sangat tinggi karena memiliki ciri khas tersendiri yang hanya di jumpai di kepulauan Mentawai. Pelaku usaha yang menjadi mitra dalam pengabdian ini adalah Usaha kerajinan Inu dan Usaha Kerupuk sagu.

Alasan pemilihan pelaku usaha ini menjadi mitra karena pelaku usaha ingin mengembangkan usahanya secara konsisten dan terus menerus, belum pernahnya pelaku usaha kerajinan Inu dan Usaha Kerupuk Sagu mendapatkan pelatihan dan pendampingan peningkatan produksi dan penjualan serta menggunakan media online dengan sehingga pelaku usaha tersebut nantinya mampu meningkatkan penjualannya dan meningkatkan produksinya. Problema yang sering dihadapi mitra usaha ini yaitu masalah penjualan kerajinan Inu dan Kerupuk sagu karena hanya masyarakat setempat yang hanya membeli dan masyarakat tersebut hanya membeli pada waktu - waktu tertentu saja, seperti untuk pernikahan atau acara adat. Jika mereka ingin melakukan penjualan di luar pulau Mentawai, maka mereka terkendala dalam biaya pengiriman karena kondisi tempat mereka berada di kepulauan yang jauh dari pusat kota.

Oleh sebab itu penting kiranya pelaku usaha mitra ini mengetahui dan memahami sistematika produksi yang tepat dan meningkatkan penjualan juga mengemas produk dengan baik serta dengan menggunakan media Promosi sehingga dapat memaksimalkan penjulannya 


\section{Rangkiang: Jurnal Pengabdian Pada Masyarakat LPSM STKIP PGR/ Sumatera Barat}

ISSN: (2721-2688) Vol. 1, Vo, 2 (Desember 2019): 41- 52

https://doi.org/10.22202/JR.2020.V1i2.3821

dan dapat meningkatkan produksinya sehingga dapat diketahui jumlah laba atau rugi yang diperoleh dari penjualan tersebut. Untuk itu pelaku usaha kerajinan Inu dan Kerupuk Sagu ini membutuhkan pelatihan dan pendampingan juga dalam pengemasan produksi sehingga dapat meningkatkan penjualan dan meningkatkan produksinya. Menurut (Fithri, Utomo, \& Nugraha, 2017) Implementasi teknologi informasi dalam dunia pemasaran, salah satunya melalui penerapan media pemasaran berbasis e-commerce populer.

Salah satu yang yang dilakukan adalah dengan bergabung di market Place Bukalapak. https://www.bukalapak.com/u/kerajinaninukerupuksagu. Melalui media tersebut memungkinkan akses informasi untuk promosi serta pemasaran dapat dilakukan seluas - luasnya tanpa terbatas ruang dan waktu. Untuk itu dibutuhkan suatu akses yang cepat dan praktis digunakan seperti menggunakan aplikasi yang ada secara online. E Commerce merupakan media yang mampu meningkatkan hasil penjualan. Menurut (Kosasi, 2015). E Commerce mampu memperluas area pangsa pasar dan upaya untuk meningkatkan volume penjualan dengan cara membangun hubungan komunikasi yang bersifat interaktif dengan konsumen (pelanggan). Menurut (Maulana, Susilo, \& Riyadi, 2015) Penggunaan internet untuk aktivitas transaksi bisnis dikenal dengan istilah Electronic Commerce (E-Commerce). E-Commerce dapat terjadi antara organisasi bisnis dengan konsumen, meliputi penggunaan Internet dan World Wide Web untuk penjualan produk dan pelayanan untuk konsumen.

Pemasaran Menurut William J. Stanton dalam bukunya Fundamental of Marketing, Pemasaran merupakan sistem keseluruhan dari berbagai kegiatan bisnis atau usaha yang ditujukan untuk merencanakan, menentukan harga barang atau jasa, mempromosikannya, dan mendistribusikannya kepada konsumen dan bisa memuaskan konsumen. Phillip Kotler dan Garry Amstrong dalam bukunya Principles of Marekting 14 edition, Pemasaran, lebih dari fungsi bisnis lainnya, berkaitan dengan pelanggan. Meskipun kami akan segera mengeksplorasi definisi yang lebih rinci pemasaran, mungkin definisi yang paling sederhana salah satunya adalah : Pemasaran adalah memiliki tujuan utama mengelola profit. Tujuan pemasaran adalah untuk menarik pelanggan baru dengan menjanjikan nilai unggul dan terus dan tumbuh yang saat ini terus memberikan kepuasan pelanggan.

Berdasarkan rekomendasi diatas maka pemasaran adalah seluruh sistem kegiatan bisnis baik dari merencanakan, menentukan barang dan jasa, mempromosikan dan mendistribusikan yang semuanya untuk tujuan menarik pelanggan baru, memberikan nilai unggul dan secara terus dan tumbuh memberikan kepuasan pelangan. Berdasarkan Bauran Pemasaran (Marketing Mix) Philips Kotler dan Amstrong (2004), Komponennya Product : Jenis Produk, Mutu, Rancangan, Ciri, Merk, Kemasan, Ukuran, Pelayanan, Garansi. Pada komponen Place : Saluran, Cakupan, Pilihan, Lokasi, Persediaan, Pengangkutan,: Logistik. Pada komponen Price : Pecantuman harga, Periode, Pembayaran, Komponen terakhir Promotion : Periklanan, Penjualan, Personel, Promosi, Penjualan dan Hubungan Masyarakat. Taktik pemasaran untuk mengimplementasikan tujuan dan strategi berdasarkan pada elemen marketing mix dan model bagaimana cara untuk menggerakkan pelanggan melalui siklus kehidupan sebagai bagian cari Customer Relationship Management (CRM).

Menurut Strauss dan Frost (2009), brand atau merek adalah salah satu atribut yang penting dari sebuah produk yang penggunaannya pada saat ini sudah sangat meluas. Selain itu brand merupakan identitas untuk membedakan produk perusahaan dengan produk yang dihasilkan pesaing. Image konsumen yang positif terhadap suatu brand lebih memungkinkan konsumen untuk melakukan pembelian. Berdasarkan analisis SWOT yang dilakukan, bahwa UKM dilokasi berdasarkan sampel antara lain : kekuatan = produk Asli daerah, reputasi yang baik, desain produk, produk inovatif; kelemahan = desain produk, desain sesuai 


\section{Rangkiang: Lurna/ Pengabdian Pada Masyarakat LPSM STKIP PGR/ Sumatera Barat}

ISSN: (2721-2688) Vol. 1, Vo, 2 (Desember 2019): 41- 52

https://doi.org/10.22202/JR.2020.V1i2.3821

pelanggan, pengembangan produk, paten, kurang terbuka, keahlian SDM, peningkatan SDM. Promosi, brand, jaringan distribusi, pemodalan; Peluang $=$ peningkatan retail, peningkatan pasar yang lebih luas, jaringan distribusi, jaringan internet, promosi, penentuan lokasi pasar, pemasaran ke sentra UMKM, marketing online, dukungan pengrajin; hambatan = dukungan departemen perindustrian, dukungan koperasi dan umkm, produk pengganti, teknologi internet Analisis Porter UMKM 1. Ancaman pesaing = produk berkualitas, pelayanan yang memuaskan

Pengembangan Produk Baru Terdapat bukti kuat yang menyatakan bahwa meluncurkan produk baru ke pasar sangatlah penting untuk menciptakan keunggulan kompetitif. Untuk mencapai kesuksesan produk baru, perusahaan harus selalu memberikan respon terhadap perubahan kebutuhan konsumen dan pergerakan para pesaingnya. Chase et al. (2001) menyatakan, karena peningkatan jumlah produk baru dan teknologi proses yang baru, sementara siklus hidup produk dan model produk semakin lama semakin pendek, maka perusahaan harus meningkatkan proyek pengembangan produk baru yang lebih besar daripada sebelumnya, dan penggunaan sumber daya yang lebih efisien pada masing-masing kegiatan.

Permasalahan yang sudah dipecahkan adalah terkait penjualan dan daya tariknya serta pemahaman terkait dengan promosi produk. Serta dasar penggunaan aplikasi online yakni, Implementasi e-Commerce menuntut pergeseran paradigma secara fundamental, dari yang semula marketplace yang menekankan interaksi secara fisik antara penjual dan pembeli menjadi marketspace yang mengandalkan transaksi elektronik. Dalam traditional marketplace, lalu lintas informasi, produk/jasa, dan pembayaran bersifat fisik (location based). Dengan kata lain, model bisnis yang berlaku adalah geographic business model. Sebaliknya, dalam dunia virtual marketplace, aliran informasi produk, proses komunikasi antara produsen dan konsumen, distribusi barang/jasa dan transaksi berlangsung dalam dunia maya/virtual.

\section{METODE}

Dalam pelaksanaan PKM kerajinan Inu dan kerupuk sagu Siberut Selatan metode pelaksanaan yang dilakukan adalah:

1. Sosialisasi, Penyuluhan dan pendampingan bagi kelompok mitra kelompok melati 2 mengenai manajemen Usaha. Dalam hal ini kelompok mendapatkan bimbingan dan pembinaan yang baik guna memperoleh pendampingan bagaimana melakukan proses produksi yang tepat serta pemilihan saluran pemasaran. Dalam proses pendampingan meliputi pemilihan bahan utama yang telah ditentukan dalam hal ini dari kerajinan inu serta kerupuk sagu. Pemilihan motif kerajinan yang dipakai dalam kerajinan tetap dalam mempertahankan budaya lokal. Serta sagu yang berkualitas. Cara pengolahan yang tepat, dan pengemasan yang menarik.

2. Persiapan dan pendataan peserta pelatihan. Persiapan dilakukan dalam rangka mempersiapkan peserta, mempersiapkan pelatih, bahan yang diperlukan, dan tempat pelatihan, serta memastikan jadwal.

3. Pendampingan akan berperan aktif dalam memberikan materi pelatihan dan praktik memproduksi pembuatan kerajinan inu dan kerupuk sagu mentawai, terutama dalam hal teknik pembuatan dan kreasinya sehingga hasil produksinya bagus dan bisa menarik pasar

4. Pendampingan Pemasaran produk dan manajemen usaha. Selama ini kelompok mitra dalam menghasilkan kerajinan inu dan kerupuk sagu tentang bagimana mereka akan pasarkan hasil produksi mereka. Kedepannya mitra dapat memasarkan produk dan 
memenuhi pesanan dari masyarakat lokal ataupun mancanegara. Solusi untuk pemasaran ini dengan menyediakan pondok promosi dan mengunakan saluran promosi dengan membuat marketplace di BUKALAPAK https://www.bukalapak.com/u/kerajinaninukerupuksagu

5. Selama pelaksanaan kegiatan tim pengusul selalu berkoordinasi dengan mitra sehingga dalam prosesnya mitra memahami dan dapat menjalankan secara mandiri atas teknologi yang telah ditransfer melalui kegiatan pelatihan dan pendampingan secara intensif dari masing masing kegiatan. Dalam pelaksanaan PKM ini tim pelaksana selalu mengevaluasi dan melaporkan setiap kegiatan yang telah dilaksanakan sampai semua kegiatan terealisasi.

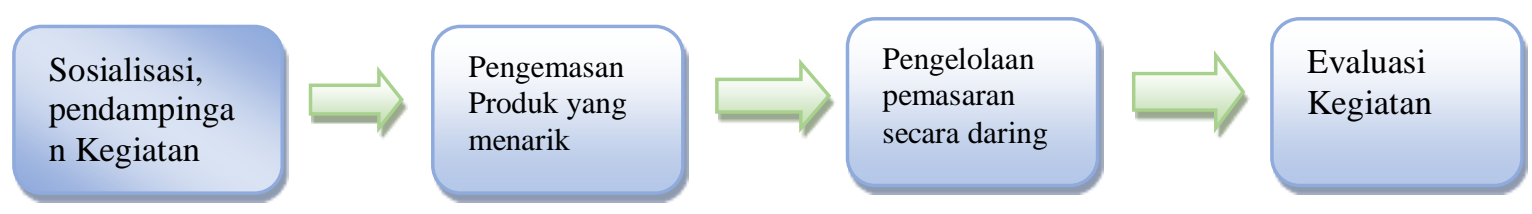

Gambar 1. Prosedur Kegiatan

\section{Sosialisasi pendampingan kegiatan.}

Kegiatan dilaksanakan dengan mengunjungi mitra yang telah dipilih yaitu Ibu Saltina sebagai ketua kelompok Melati 2 didampinggi oleh beberapa anggota yang berkesempatan hadir. Pada kegiatan sosialisasi disampaikan informasi- informasi mengenai latar belakang, target, sasaran dan tujuan kegiatan. Indikator tersebut memiliki satu tujuan yaitu pengembangan dan keberlanjutan fasilitas produksi kerajinan inu dan kerupuk sagu, serta peningkatan hasil penjualan mitra. Selain itu pelaksana kegiatan menyampaikan jadwal kegiatan pengabdian yang diselenggarakan.

\section{Pengemasan produk yang lebih menarik}

Bantuan kemasan berupa mesin press kemasan, blender Philips untuk bahan bahan kerupuk sagu Mesin jahit Portable untuk mempermudah penjahitan, pembuatan desain inu yang menarik. Kemasan produk kerupuk sagu menjadi penting karena desain kemasan dan merk yang menarik memiliki nilai jual yang lebih tinggi seiring dengan proses diskusi mengenai logo atau merek usaha yang dipakai, juga dilakukan diskusi mengenai penentuan desain kemasan produk yang akan diterapkan. Bagi UMKM bidang kerajinan dan kuliner, manfaat pelatihan sangat terasa karena para pelaku usaha di bidang ini dapat membuat berbagai alternatif desain untuk kemasan produknya, sehingga tampilan produknya lebih variatif, menarik (eye catching), namun masih tetap terjaga kualitas produknya (Rofieq, Poerwanto, \& Budiyanto, 2017).

\section{Pengelolaan pemasaran secara daring}

Pelatihan dan bantuan sistem pemasaran yang lebih baik dan tidak hanya berfokus kepada menunggu pemesanan oleh pelanggan, namun juga secara proaktif melakukan pemasaran melalui website dibidang teknologi informasi dan komputer. Pelatihan penggunaan aplikasi e-commerce berbasis web yang telah dilaksanakan dapat memberikan kemampuan dalam mengorganisir pesanan konsumen serta dapat memudahkan pengguna untuk menampilkan status setiap barang dalam transaksi online dengan mengaplikasikan dalam kegiatan pelatihan. Dalam persaingan yang ketat ini perusahaan perlu mengetahui secara rinci hal-hal yang menimbulkan daya tarik untuk membeli produk yang dibuat kelompok mitra. 


\section{Rangkiang: Jurnal Pengabdian Pada Masyarakat LPSM STKIP PGR/ Sumatera Barat}

ISSN: (2721-2688) Vol. 1, Vo, 2 (Desember 2019): 41- 52

https://doi.org/10.22202/JR.2020.V1i2.3821

Namun pengembangan dan implementasi website $e$-commerce untuk proses promosi serta pemasaran produk kerajinan inu dan kerupuk sagu tidak berjalan sesuai dengan yang direncanakan karena terbatasnya akses internet bagi kelompok dan juga keterbatasan SDM yang mereka miliki, sehingga setelah melalui proses dari awal pengenalan media $e$ commerce sampai dengan implementasinya terkendala akses. Proses awal tersebut dimulai dari analisa dan perancangan sistem, pengembangan sistem, penerapan sistem serta tahap evaluasi sistem.

Hasil kegiatan pengabdian pada masyarakat ini telah sesuai dengan rancangan dan rencana evaluasi. Salah satu implementasi dari kegiatan pengabdian ini adalah sudah diterapkannya pengembangan usaha dan pemasaran yang tepat serta kelompok mitra mendirikan pondok promosi sebagai media promosi alternatif. Dengan tercapainya kedua tujuan dari kegiatan pendampingan ini, maka mitra telah memiliki kemasan baru yang lebih informatif dan menarik. Pada kemasan tersebut terdapat pilihan rasa dan nomor handphone mitra, serta informasi lain berupa alamat google maps, logo mitra dan alamat mitra dapat dengan mudah diketahui konsumen.

Hasil uji pasar terkait kemasan baru menunjukkan adanya peningkatan jumlah penjualan produk kerajinan inu dan kerupuk sagu dibandingkan tampilan fisik sebelumnya, namun dari segi harga belum menjadi ancaman daya beli konsumen karena kemasan yang lebih baik sering dipesan untuk dijadikan buah tangan maupun untuk konsumsi pribadi. Mitra juga menyatakan bahwa munculnya beberapa pelanggan baru yang menghubungi melalui nomor handphone yang tertera pada kotak kemasan maupun ada pula yang melihat dari internet dan juga mendapat informasi pada saat pelaksanaan festival pesona mentawai yang diadakan oleh pemerintah kabupaten mentawai pada waktu yang lalu.

\section{Evaluasi kegiatan}

Evaluasi kegiatan pelatihan dilakukan setelah pelatihan pengelolaan dan pemasaran. Evaluasi kegiatan dilakukan untuk mengetahui keberhasilan kegiatan pelatihan yang dilaksanakan. Setelah pelaksanaan kegiatan dilakukan, maka langkah selanjutnya adalah melakukan evaluasi oleh ketua dan anggota pengabdian masyarakat. Membahas evaluasi dari perencanaan dan pelaksanaan serta laporan kemajuan kegiatan, pelaksanaan kegiatan pengabdian masyarakat tentang PKM kerajinan inu dan kerupuk sagu siberut terlaksana sesuai dengan rencana, sesuai dengan sosialisasi dan pelatihan serta memberikan dukungan alat penunjang. Mitra sangat antusias dan kami mendapat masukan bahwa kegiatan pelatihan khususnya pelatihan proses produksi dan pelatihan mengemas dengan baik dilakukan pembaharuan informasi dengan cepat, karena hal ini dapat memberikan dampak langsung terhadap konsumen dengan cepat dan praktis. Evaluasi dilakukan dengan melakukan FGD dengan para pihak terkait antara pelaksana pengabdian, pihak Kecamatan dan kelompok mitra usaha tentang pemahaman mitra selama berjalannya proses PKM.

\section{HASIL DAN PEMBAHASAN}

Kegiatan pengabdian ini terselenggara berkat kerja sama antara perguruan tinggi pengusul dan dibiayai Oleh DRPM TA 2019 dengan pihak kelompok mitra usaha di Dusun Batjoja. Kegiatan penyuluhan dan pendampingan ini merupakan salah satu tahapan penting dari kegiatan pengabdian kepada masyarakat yang merupakan bagian dari Tri Dharma Perguruan tinggi. Pendampingan dan pelatihan dilakukan di Dusun Batjoja Desa Meilepet Kecamatan Siberut Selatan. Dalam pelaksanaannya kegiatan pendampingan kepada kelompok mitra ini mendapat dukungan penuh mulai dari unsur Kecamatan sampai dengan 


\section{Rangkiang: Jurnal Pengabdian Pada Masyarakat LPSM STKIP PGR/ Sumatera Barat}

ISSN: (2721-2688) Vol. 1, Vo, 2 (Desember 2019): 41- 52

https://doi.org/10.22202/JR.2020.V1i2.3821

perangkat Desa. Sebagai wujud dari kegiatan pengabdian ini melahirkan sebuah kelompok mitra usaha kerajinan inu dan kerupuk sagu Siberut.

Metode pendekatan dan bimbingan yang bermaksud untuk memotivasi kelompok mitra untuk mengembangkan hasil usaha mereka dan juga meningkatkan potensi sumber daya yang mereka miliki dalam hal ini juga bagaimana mitra mempertahankan kearifan budaya lokal yang mereka miliki dalam menghasilkan kreasi. Sumber daya yang terpenting dimiliki oleh kelompok mitra yaitu sumberdaya yang dimiliki oleh masyarakat Dusun Batjoja dalam pengembangan ekonomi keluarga.

Kegiatan-kegiatan yang telah dilaksanakan oleh team PKM yaitu:

1. Pengurusan administrasi berupa surat izin pengabdian, mulai dari Dinas Penanaman Modal dan Pelayanan Satu Pintu, Kesbangpol Provinsi, Kantor Kesbangpol Kab Kep. Mentawai, Bapedda Kab. Kep. Mentawai.

2. Kerjasama dengan pihak Desa untuk melaksanakan PKM dengan saling mendukung agar meningkat pemahaman masyarakat tentang kebencanaan.

3. Kerjasama dengan Kelompok mitra usaha Setelah terjalin kerjasama yang baik, kegiatan pengabdian pada masyarakat di Dusun Batjoja untuk membantu PKM yang akan di laksanakan di lingkungan mereka.

4. Mendirikan pondok promosi yang Sangat bermanfaat bagi keberlangsungan aktivitas kegiatan usaha mereka.

5. Melaporkan hasil pelaksanaan kegiatan Pengabdian kepada pemerintah Kabupaten Kepulauan

Tabel 1. Uraian Kegiatan PKM (Langkah-langkah Solusi atas Persoalan Mitra)

\begin{tabular}{|c|c|c|c|c|c|c|}
\hline No & Uraian Kegiatan & Lokasi & Waktu & Sarana & $\begin{array}{l}\text { Jumlah } \\
\text { Peserta }\end{array}$ & $\begin{array}{l}\text { Partisipasi } \\
\text { Mitra }\end{array}$ \\
\hline 1 & $\begin{array}{l}\text { Bimbingan \& } \\
\text { pendampingan } \\
\text { manajemen usaha } \\
\text { : } \\
\text { Pengemasan } \\
\text { kerupuk sagu dan } \\
\text { kerajinan inu }\end{array}$ & $\begin{array}{l}\text { Dusun } \\
\text { Batjoja }\end{array}$ & Bulan 4, 5 & $\begin{array}{l}\text { Kemasan } \\
\text { produk, } \\
\text { catatan } \\
\text { informasi } \\
\text { produksi, } \\
\text { ATK, }\end{array}$ & 13 & $\begin{array}{l}\text { Terlibat } \\
\text { dalam } \\
\text { kegiatan }\end{array}$ \\
\hline 2 & $\begin{array}{l}\text { Pemasaran } \\
\text { produk membuat } \\
\text { market place } \\
\text { berupa } \\
\text { penggunaan } \\
\text { media } \\
\text { Ecommerce } \\
\text { dalam saluran } \\
\text { pemasaran }\end{array}$ & $\begin{array}{l}\text { Dusun } \\
\text { Batjoja }\end{array}$ & Bulan 5 & $\begin{array}{l}\text { Pondok } \\
\text { promosi, } \\
\text { produk }\end{array}$ & 13 & $\begin{array}{l}\text { Terlibat } \\
\text { dalam } \\
\text { kegiatan }\end{array}$ \\
\hline 3 & $\begin{array}{l}\text { Monitoring dan } \\
\text { evaluasi kegiatan }\end{array}$ & $\begin{array}{l}\text { Dusun } \\
\text { Batjoja }\end{array}$ & Bulan 5 & $\begin{array}{l}\text { FGD, } \\
\text { catatan }\end{array}$ & 13 & $\begin{array}{l}\text { Terlibat } \\
\text { dalam } \\
\text { kegiatan }\end{array}$ \\
\hline
\end{tabular}

Pada tabel 1 dapat dilihat lanjutan rangkaian kegiatan pengabdian dalam mengembangkan industry kerajinan dimana harus dimulai dari ide yang terus muncul oleh mitra seerta tingkat reativitas, kemauan, bakat, potensi dan kemampuan anggota kelompok dalam menjalankan aktivitasnya. Pada kegiatan pengabdian yang telah dilakukan kelompok 
mitra dan berdasarkan evaluasi dari beberapa aktivitas yang telah dilakukan maka sudah dapat dilihat bagaimana keinginan dari kelompok melati 2 dalam mewujudkan nilai keberhasilan dari kegiatan yang dilakukan. Semangat dalam melakukan setiap kegiatan, namun hanya saja tetap dalam memulai aktivitas selanjutnya mereka masih sangat bertumpu pada hasil dari kegiatan yang sebelumnya. Berdasarkan pengamatan yang telah dilakukan di lapangan dapat dilihat beberapa perkembangan dari kegiatan yang dilakukan sebelumnya diantaranya adalah:

Tabel 2. Aktivitas yang telah dilakukan setelah Evaluasi

\begin{tabular}{lllllll}
\hline & $\begin{array}{l}\text { Tenaga } \\
\text { Kerja }\end{array}$ & Modal & Keahlian & Pemberdayaan & $\begin{array}{l}\text { Semangat } \\
\text { bekerja }\end{array}$ & pemasaran \\
\hline Bagus & $\sqrt{ }$ & & $\sqrt{ }$ & $\sqrt{ }$ & $\sqrt{ }$ \\
Cukup & & $\sqrt{ }$ & & $\sqrt{ }$ & & \\
Sedang & & & & & & \\
Kurang & & & & & & \\
\hline
\end{tabular}

Dari tabel 2 diatas, dapat dilihat bahwas telah terjadi perbaikan aktivitas dari sebelum pendampingan ada dua hal prioritas yang dapat dibutuhkan dan dikembangkan dalam meningkatkan penghasilan dan pemberdayaan kelompok mitra adalah bagaimana memaksimalkan modal yang dimiliki, dalam artian kelompok mitra harus lebih meningkatkan potensi yang dimiliki disamping besaran uang yang harus disediakan untuk mengembangkan usaha. Serta, pengembangan kemampuan dalam memproduksi produk mitra sudah memperlihatkan keserriusan dan dengan cara memberikan selalu motivasi kepada kelompok mitra.

\section{PKM Kerajinan Inu dan Kerupuk Sagu Siberut, Desa Meileppet}

Tim Pengabdian Masyarakat telah mengupayakan solusi, karena pemasaran merupakan ujung tombak yang sangat menentukan untuk perluasan usaha. Salah satu solusi adalah mengembangkan penjualan secara online. Penjualan dilakukan dengan cara menggunakan media perantara guna mempromosikan semua jenis produk yang telah dibuat oleh kelompok mitra.

Usaha tersebut di sosialisasikan dalam pengabdian ini melalui media sosial seperti IG, dan BUKALAPAK https://www.bukalapak.com/u/kerajinaninukerupuksagu. Merek dan kemasan telah di desain sedemikian rupa dan diharapkan akan semakin dikenal, Tim Pengabdi juga telah memberikan pembekalan untuk mitra berupa "Smart Packaging" melalui pelatihan dan sosialisasi mengenai kemasan yang cocok dan tepat dalam menarik calon pelanggan, kemasan "standing poch" dengan seal, yang lebih fleksibel dan menarik dengan berbagai ukuran. Kemasan sudah siap untuk ditempel stiker merek lengkap dengan labelnya. Serta telah banyak pesanan berdatangan terutama dari luar kabupaten Kepulauan Mentawai. Berikut ada beberapa hasil dari kegiatan yang telah dilakukan oleh kelompok Melati 2: 


\section{Rangkiang: Lurnal Pengabdian Pada Masyarakat LPSM STKIP PGR/ Sumatera Barat}

ISSN: (2721-2688) Vol. 1, Vo, 2 (Desember 2019): 41- 52

https://doi.org/10.22202/JR.2020.V1i2.3821

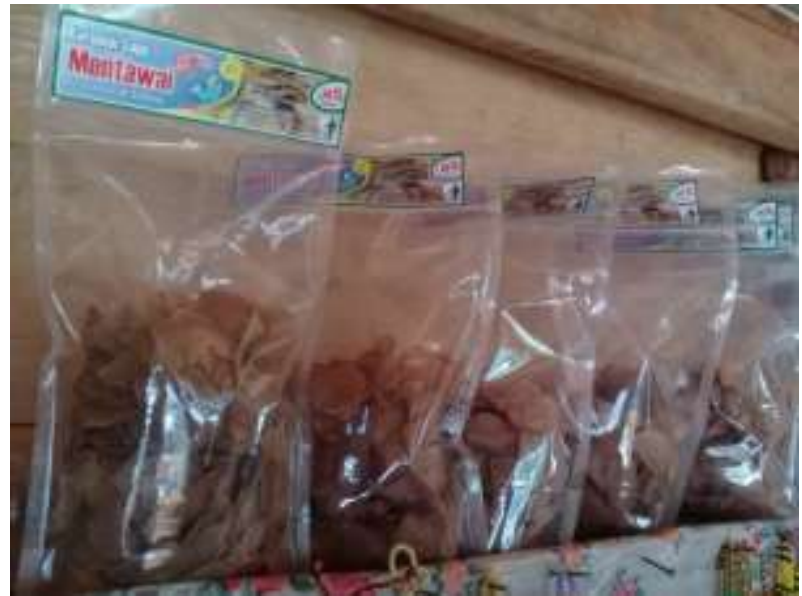

Gambar 2. Kerupuk sagu yang telah dikemas

Kerupuk sagu yang telah dikemas dengan baik dan dipajang di salah satu sudat pondok promosi dimana para pelanggan bisa memilih kerupuk yang akan dibeli. Kegiatan pemasaran juga sudah sering dilakukan guna memperkenalkan salah satu makanan alternative masyarakat yang berbahan sagu yakni makanan tradisional daerah Mentawai.

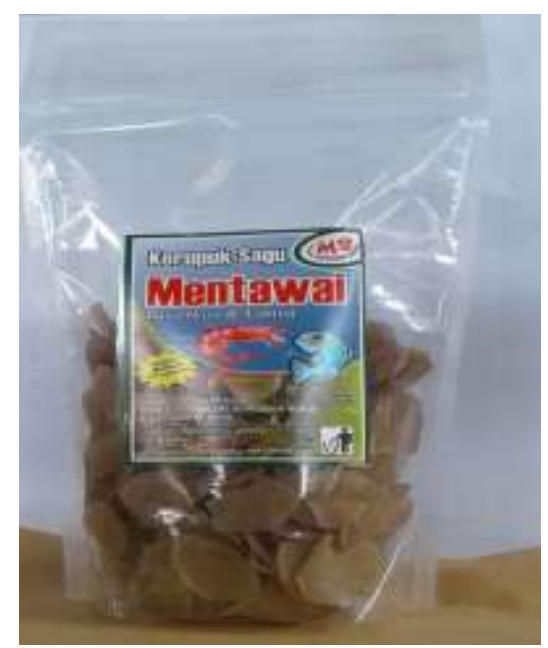

Gambar 3. Kerupuk sagu dengan merek M2

Kerajinan inu adalah salah satu bentuk kerajinan asli masyarakat mentawai dimana terdiri dari beberapa jenis kerajinan ada yang bernama sobbe, luat, lai-lai tengah, lek kau, inu polos, inu sitede, sikairat, inu jodoh, inu motif, inu ugei, kesemua jenis kerajinan tersebut dipakai pada acara acara adat atau ada kegiatan di suatu lokasi dimentawai. Maka dari itu juga ada beberapa potensi untuk di perjual belikan berdasarkan permintaan pesanan, biasanya paling sering di pesan dalam acara sanggar kesenian mentawai. 


\section{Rangkiang: Lurna/ Pengabdian Pada Masyarakat LPSM STKIP PGR/ Sumatera Barat}

ISSN: (2721-2688) Vol. 1, Vo, 2 (Desember 2019): 41- 52

https://doi.org/10.22202/JR.2020.V1i2.3821
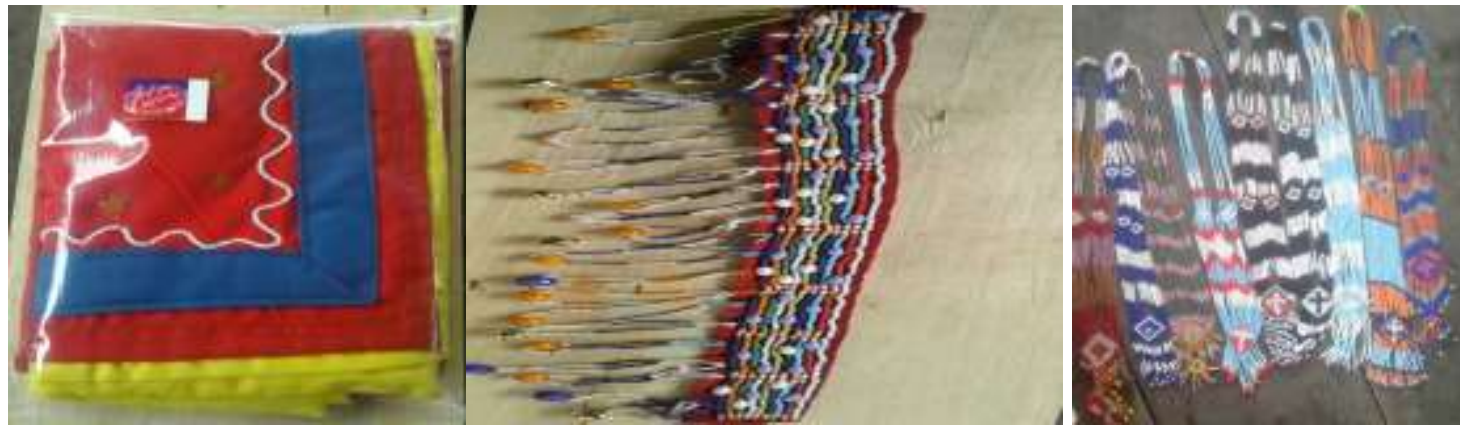

Gambar 4. Kerajinan Inu
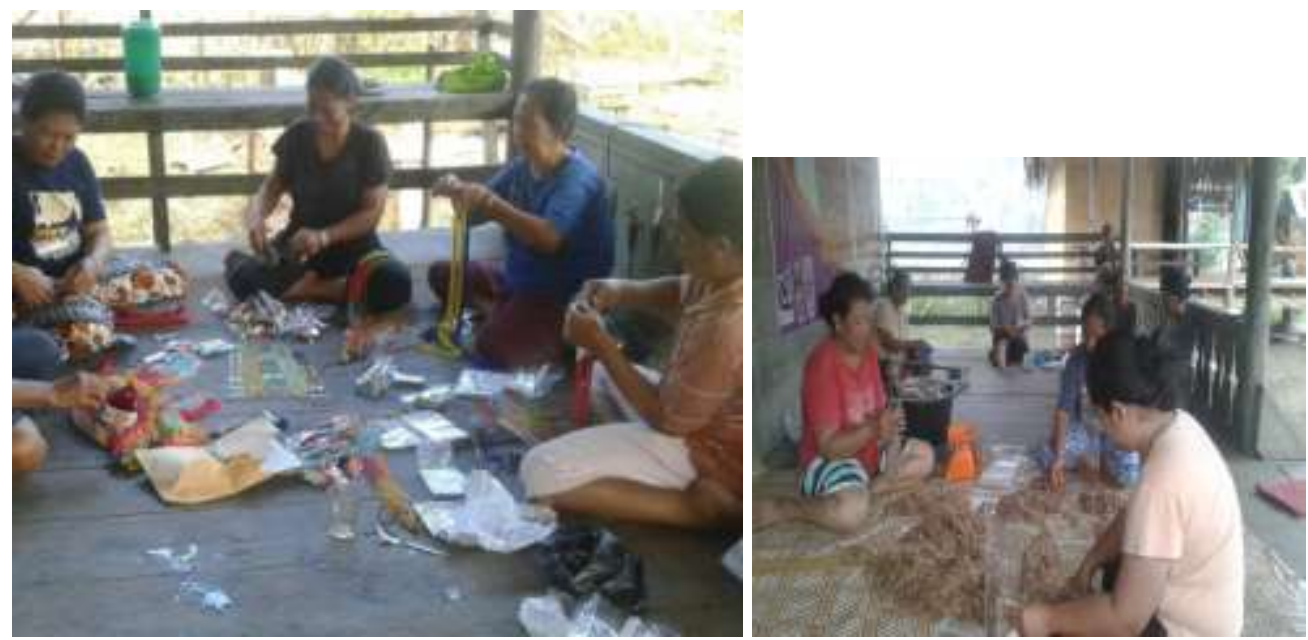

Gambar 5: Ibu-ibu kelompok melati 2 sedang packing inu dan kerupuk sagu

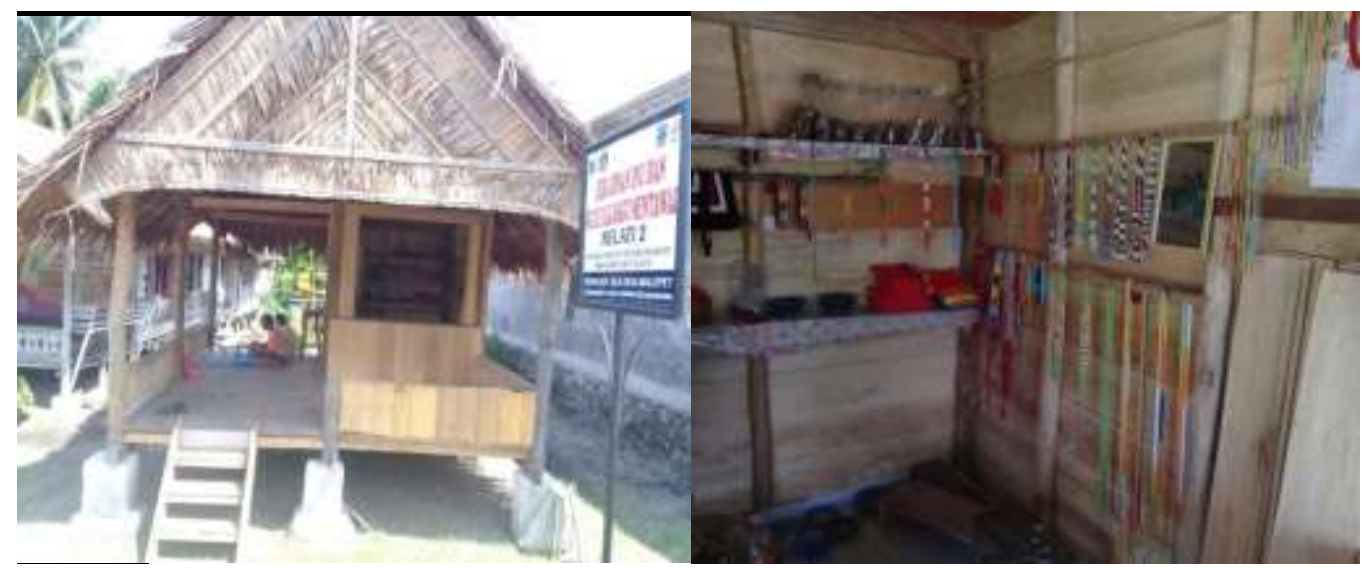

Gambar 6. Pojok Promosi yang disediakan dipondok promosi Melati 2

Pondok promosi didirikan secara swadaya dan gotong royong dari partisipasi semua anggota dimana keinginan untuk mendirikan salah satu tempat bagi mereka dalam melakukan kegiatan, dimana sebelumnya mereka hanya berpindah-pindah untuk mengerjakan kegiatan. Tetapi dengan adanya semangat dan keinginan dari kelompok, maka mereka mau mendirikan sebuah tempat untuk kelompok berkegiatan termasuk membuat pojok promosi. Keberhasilan tim pelaksana dalam menjalankan aktivitas pendampingan dan pelatihan bagi kelompok melati 2 ditandai dengan banyaknya permintaan pesanan dari beberapa kebutuhan telah terpenuhi. Juga dapat dilihat bahwa sudah adanya list harga sehingga calon pembeli pun 


\section{Rangkiang: Lurnal Pengabdian Pada Masyarakat UPSM STKIP PGRl Sumatera Barat}

ISSN: (2721-2688) Vol. 1, Vo, 2 (Desember 2019): 41- 52

https://doi.org/10.22202/JR.2020.V1i2.3821

dapat memperkirakan berapa jumlah kerajinan ataupun kerupuk sagu yang akan mereka beli dan konsumsi.

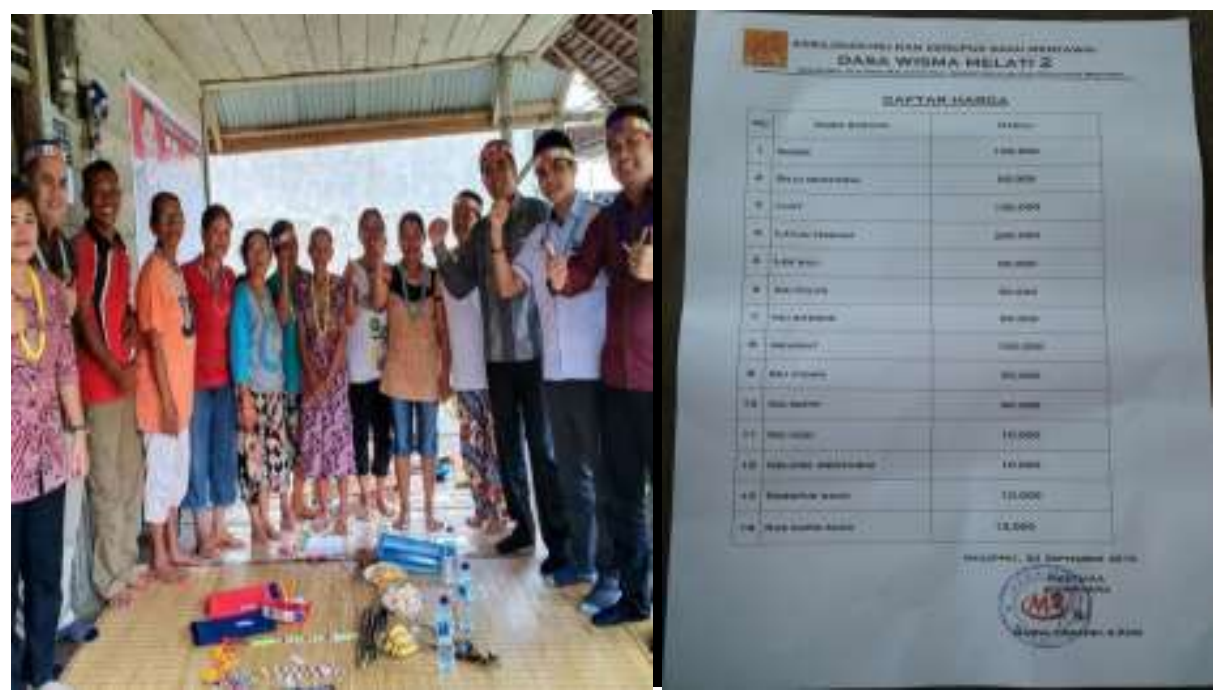

Gambar 7. Foto bersama kelompok melati 2 dan list harga yang telah ditetapkan.

\section{PENUTUP}

Kelompok Melati 2 dalam menjalankan usaha mempunyai potensi dalam menghasilkan nilai dan uang. Meskipun penjualan dari produk yang dihasilkan yakni kerajinan inu dan kerupuk sagu sudah semakin bagus secara lokal namun pemerataan penjualan dan pemasaran produk sudah Sangat bagus dan banyak yang berminat, namun hanya saja potensi promosi yang dilakukan harus selalu dilakukan, terlebih untuk pemasaran diluar Pulau ataupun luar Kabupaten sehingga dalam peningkatan ekonomi kelompok mitra khususnya akan semakin meningkati. Hal ini juga didasari oleh informasi dan edukasi yang dimiliki oleh kelompok mitra dalam hal proses produksi dan pemilihan pemasaran.

Pengembangan yang dilakukan berjalan secara opimal dan berkelanjutan sesuai dengan kemampuan, kemauan, bakat dan potensi yang dimilik oleh kelompok mitra. Untuk itu kedepannya diperlukan lagi keberlanjutan pendampingan guna mengoptimalisasikan setiap faktor penting dalam pengembangan kerajinan dan usaha kelompok untuk keberlangsungan hidup keluarga serta daya tarik desa yang ada di Meillepet khusunya di Dusun Batjoja. Peran yang diberikan oleh pemerintah Kecamatan harus mampu di maksimalkan bagi anggota mitra guna keberlanjutan kelompok usaha untuk pengembangan ke Nasional ataupun Mancanegara

\section{UCAPAN TERIMAKASIH}

Terima kasih kepada Direktorat Riset dan Pengabdian Masyarakat Kementerian Riset Teknologi dan Pendidikan Tinggi yang telah membiayai kegiatan pengabdian mono tahun ini melalui dana DRPM Tahun 2019 dengan judul "PKM Kerajinan Inu dan Kerupuk Sagu Siberut Selatan“ pelaksana juga berterima kasih kepada Kelompok Melati 2 yang telah berkontribusi dan mau bekerjasama dan juga semua pihak yang terkait bekerja keras dalam membantu pengabdian ini. Dengan akhirnya tim juga berkeinginan terus melakukan pemantauan terhadap keberlanjutan usaha kelompok Melati 2.

\section{DAFTAR PUSTAKA}


Anggraeni, F. D., Hardjanto, I., \& Hayat, A. (2013). Pengembangan Usaha Mikro, Kecil, dan Menengah (UMKM) Melalui Fasilitas Pihak Eksternal dan Potensi Internal. Jurnal Administrasi Publik, 1(6), 1286-1295.

Darwanto. 2013. Peningkatan Daya Saing UMKM Berbasis Inovasi dan Kreativitas. Jurnal Bisnis dan Ekonomi. Hal. 142-149. Vol 20, No. 2.

Fithri, D. L., Utomo, A. P., \& Nugraha, F. (2017). Pemanfaatan E-Commerce Populer Untuk Optimalisasi. Jurnal Simetris, 8(2), 819-824.

Harto, D., Pratiwi, S.R., Utomo, M.N. and Rahmawati, M., 2019. PENERAPAN INTERNET MARKETING DALAM MENINGKATKAN INTERNET MARKETING IMPLEMENTATION

Kosasi, S. (2015). Perancangan Sistem E-Commerce Untuk Memperluas Pasar Produk OlehOleh Khas Pontianak. Snastia, 2015(Oktober), 110-119.

Pattinama, M. J., (2009), Pengentasan Kemiskinan Dengan Kearifan Lokal (Studi Kasus di Pulau Buru-Maluku dan Surade-Jawa Barat), Jurnal Makara Sosial Humaniora, 13 (1), $1-12$

Maulana, S. M., Susilo, H., \& Riyadi. (2015). Implementasi E-Commerce Sebagai Media Penjualan Online. Jurnal Administrasi Bisnis( JAB), 29(1), 1-9

Murdani , Sus Widayani, H., 2019. Pengembangan Ekonomi Masyarakat Melalui Pemberdayaan Usaha Mikro Kecil dan Menengah (Studi di Kelurahan Kandri Kecamatan Gunungpati Kota Semarang). 23(2), pp.152-157

Sahudiyono (2009), Memberdayakan Masyarakat Pesisir dengan Pendekatan Program Pemberdayaan Ekonomi Masyarakat Pesisir (PEMP), Jurnal Riset Daerah BAPEDA Bantul, 7(3), 1169-1189 